\title{
Memory phenotype CD8+ T-cells with innate function selectively develop in the absence of active Itk
}

\author{
Jianfang $\mathrm{Hu}^{1,2}$, Nisebita Sahu ${ }^{1,3}$, Elizabeth Walsh ${ }^{1,4}$, and Avery August ${ }^{1,5}$ \\ ${ }^{1}$ Center for Molecular Immunology \& Infectious Disease and Department of Veterinary \& Biomedical \\ Sciences, The Pennsylvania State University, University Park, PA 16802 \\ ${ }^{2}$ Immunology \& Infectious Disease Graduate Program, The Pennsylvania State University, \\ University Park, PA 16802 \\ ${ }^{3}$ Department of Biochemistry \& Molecular Biology, The Pennsylvania State University, University \\ Park, PA 16802 \\ ${ }^{4}$ Pathobiology Graduate Program, The Pennsylvania State University, University Park, PA 16802
}

\section{Summary}

T cells with a memory like phenotype and possessing innate immune function have been previously identified as $\mathrm{CD} 8{ }^{+} \mathrm{CD} 44^{\mathrm{hi}}$ cells. These cells rapidly secrete IFN $\gamma$ upon stimulation with IL-12/IL-18 and are involved in innate responses to infection with Listeria monocytogenes. The signals regulating these cells are unclear. The Tec kinase Itk regulates $T$ cell activation and we report here that a majority of the $\mathrm{CD} 8^{+} \mathrm{T}$ cells in Itk null mice have a phenotype of $\mathrm{CD} 44^{\mathrm{hi}}$ similar to memory like innate $\mathrm{T}$ cells. These cells are observed in mice carrying an Itk mutant lacking the kinase domain, indicating that active Tec kinase signaling suppresses their presence. These cells carry preformed message for and are able to rapidly produce IFN $\gamma$ upon stimulation in vitro with IL-12/IL-18, and endow Itk null mice the ability to effectively respond to infection with $L$. monocytogenes or exposure to LPS by secretion of IFN $\gamma$. Transfer of these cells rescues the ability of IFN $\gamma$ null mice to reduce bacterial burden following $L$. monocytogenes infection indicating that these cells are functional $\mathrm{CD} 8{ }^{+} \mathrm{CD} 44^{\mathrm{hi}} \mathrm{T}$ cells previously detected in vivo. These results indicate that active signals from Tec kinases regulate the development of memory like $\mathrm{CD} 8^{+} \mathrm{T}$ cells with innate function.

\section{Keywords \\ Listeria monocytogenes; Itk; IFN $\gamma$; IL-12}

\section{Introduction}

Itk, a Tec family kinase, regulates signals emanating from the T cell Receptor [1-4]. Mice lacking Itk have reduced numbers of $\mathrm{CD} 4^{+} \mathrm{T}$ cells, and these cells exhibit reduced proliferation and IL-2 production in vitro and in vivo [3-5]. Itk also modulates the differentiation of helper $\mathrm{T}$ cells into Th 2 cells, or alternatively, controls their production of Th 2 cytokines such as IL-4 [6-8]. Indeed, infection of Itk deficient mice on a Balb/c background with parasites such as $S$. mansoni or L. donovani, results in the generation of a predominant Th1 response [4,6,7]. In agreement with these findings, Itk null mice are resistant to developing Th2 mediated allergic

5Address correspondence to: Dr. Avery August, Center for Molecular Immunology \& Infectious Disease, Department of Veterinary \& Biomedical Sciences, The Pennsylvania State University, 115 Henning Building, University Park, PA 16802, 814-863-3539 (Ofc), 814-863-6140 (Fax), axa45@psu.edu. 
asthma $[9,10]$. By contrast, these mice are more susceptible to infection with the intracellular parasite $T$. gondii [2], as well as infection with VSV and LCMV [11,12].

$\mathrm{T}$ cells are generally characterized as naïve cells, generally identified as CD62 $\mathrm{L}^{\mathrm{hi}}$ and/or $\mathrm{CD} 44^{\text {lo }}$ or memory cells, generally identified as CD62 $\mathrm{L}^{\text {lo }}$ and/or CD44hi (for review see [13, 14]). Recently, a population of $\mathrm{CD} 8^{+} \mathrm{T}$ cells with "innate" like function expressing a similar memory like phenotype has been identified $[15,16]$. These cells are $\mathrm{CD} 8^{+} \mathrm{CD} 44^{\mathrm{hi}}$, can rapidly secrete IFN $\gamma$ upon stimulation with IL-12 and IL-18, and play important roles in the innate response against infections such as $L$. monocytogenes, or chronic infections with viruses such as $\gamma$ Herpes virus [16-20] (for review see [21]). The origin of these cells or the regulation of their function is poorly understood.

During analysis of mice lacking Itk, it has been noted that these mice have increased percentage of memory like $\mathrm{CD}^{+}$as well as $\mathrm{CD} 8^{+} \mathrm{T}$ cells [22-24]. Most recently, the memory like $\mathrm{CD} 8^{+} \mathrm{T}$ cells were shown to be $\mathrm{CD} 44^{\mathrm{hi}} / \mathrm{CD} 122^{+}$, and to be restricted by MHC class $1 \mathrm{~b}[22-$ 25]. Whether these cells represent the previously described innate type memory $\mathrm{T}$ cells is unclear [16-20]. We report here that a majority of the $\mathrm{CD} 8^{+} \mathrm{T}$ cells in Itk null mice have a phenotype similar to memory like $\mathrm{CD} 8^{+}$innate $\mathrm{T}$ cells. These cells do not require active Tec kinase signaling for their development, carry preformed message for IFN $\gamma$, which they are able to rapidly produce upon stimulation with IL-12/IL-18. Finally, we show that Itk null mice exhibit enhanced response to infection with L. monocytogenes in vivo and that transfer of Itk null $\mathrm{CD} 8^{+} \mathrm{CD} 44^{\mathrm{hi}}$ reduces bacterial burden in L. monocytogenes infected IFN $\gamma$ null mice. These results indicate that active signals from Tec kinases regulate the development and function of memory like $\mathrm{T}$ cells with innate function.

\section{Results}

\section{Increased presence of $\mathrm{CD}^{+} \mathrm{T}$ cells with memory like phenotype in Itk null mice}

$\mathrm{CD} 8^{+} \mathrm{CD} 44^{\text {hi }} \mathrm{T}$ cells which resemble memory cells represent an increased percentage of total $\mathrm{CD}^{+} \mathrm{T}$ cells in Itk null mice. This increased population of cells are present in the youngest mice tested (age $<1$ month) and the increase persists out to $>12$ months of age (Fig. 1a, shown for the spleen). The percentage of these cells is increased in the lymph nodes, blood and spleen of mice lacking Itk, suggesting that this is not dependent on preferential enrichment of these cells in specific tissues (data not shown). Expression of CD122, the IL-2R $\beta$ chain, has been reported to define this population of memory like $\mathrm{CD}^{+} \mathrm{T}$ cells [26], and we found that the $\mathrm{CD} 8^{+} \mathrm{CD} 44^{\text {hi }}$ population in both WT and Itk null mice expressed CD122, although the Itk null mice carry a larger percentage of these cells (Fig. 1b). Analysis of the number of $\mathrm{CD} 8^{+} \mathrm{CD} 44^{\text {hi }} \mathrm{T}$ cells in in 6-8 week old WT and Itk null mice indicated that the $\mathrm{Itk}^{-/-}$mice had significantly more of these $\mathrm{T}$ cells in the spleen (Fig. 1c). These data suggest that signals from Itk negatively regulate the development of $\mathrm{CD} 8^{+} \mathrm{T}$ cells having a memory like phenotype. Alternatively, Itk signals are required for the development of conventional $\mathrm{CD} 8^{+} \mathrm{T}$ cells expressing low levels of $\mathrm{CD} 44$ and in their absence, $\mathrm{CD} 8{ }^{+} \mathrm{CD} 44^{\mathrm{hi}} \mathrm{T}$ cells predominate.

\section{Tec kinase activity suppresses the presence of CD8 memory like T cells}

We and others have reported that the kinase domain and/or activity of Itk is dispensable for specific functions of Itk in vitro [27-29]. To determine if this domain or active signaling by Itk is required for the presence of the memory like $\mathrm{T}$ cells, we analyzed mice carrying a mutant Itk lacking the kinase domain, replaced with GFP, instead of WT Itk (Itk $\Delta \mathrm{Kin}_{\mathrm{Tg}} / \mathrm{Itk}^{-/-}$mice). These mice had the memory like $\mathrm{CD} 8^{+} \mathrm{T}$ cells similar to those seen in Itk null mice (Fig. 2a). WT mice had significantly lower percentage of $\mathrm{CD} 8^{+} \mathrm{CD} 44^{\text {hi }} \mathrm{CD} 122^{+}$than those found in $\mathrm{Itk}^{-/-}$and Itk $\Delta \mathrm{Kin} / \mathrm{Itk}^{-/-}$mice (Fig. 2b). These data indicate that active signaling by Tec 
kinases reduces the development of these cells or enhances the development of conventional $\mathrm{CD} 8^{+} \mathrm{CD} 44^{\text {lo }} \mathrm{T}$ cells.

\section{Itk $^{-/-}$memory like CD8 ${ }^{+} \mathrm{T}$ cells carry preformed message for IFNy}

To determine if these memory like $\mathrm{CD} 8^{+} \mathrm{T}$ cells exhibit similar functional behavior in vitro, we analyzed their ability to rapidly secrete IFN $\gamma$ upon stimulation. Comparison of IFN $\gamma$ production by PMA/Ionomycin stimulated $\mathrm{CD} 8{ }^{+} \mathrm{CD} 44^{\mathrm{hi}} \mathrm{T}$ cells in vitro indicates that the Itk null cells behave similar to those from WT mice in rapidly (within 6 hours) secreting this cytokine, with a similar percentage of the $\mathrm{CD} 8^{+} \mathrm{CD} 44^{\mathrm{hi}} \mathrm{T}$ cells responding from both WT and $\mathrm{Itk}^{-1-}$ mice (Fig. 3a). By contrast, $\mathrm{CD} 8^{+} \mathrm{CD} 44^{\mathrm{lo}} \mathrm{T}$ cells did not secrete any appreciable IFN $\gamma$ in this time period.

A role for memory like $\mathrm{CD} 8^{+} \mathrm{CD} 44^{\mathrm{hi}} \mathrm{T}$ cells in the early innate response following exposure to LPS or infection with the intracellular bacteria L. monocytogenes has been previously reported [18]. Infection of macrophages by L. monocytogenes results in the secretion of IL-12 and IL-18 [30], and these cytokines can stimulate $\mathrm{CD} 8^{+} \mathrm{CD} 44^{+}$memory like $\mathrm{T}$ cells to secrete IFN $\gamma$, thus activating macrophages for TNF- $\alpha$ production and bacterial clearance [19]. We therefore determined if this population is the same population that is expanded in mice lacking Itk. Analysis of IFN $\gamma$ production in cells from WT and Itk null mice stimulated in vitro with IL-12 and IL-18 revealed that WT and Itk null CD8 ${ }^{+} \mathrm{CD} 44^{\mathrm{hi}}$ secreted significant levels of this cytokine, and again a similar percentage of Itk null $\mathrm{CD} 8^{+} \mathrm{CD} 44^{\text {hi }} \mathrm{T}$ cells responded compared to WT cells (Fig. 3b). Similarly, incubation of purified CD $8^{+} \mathrm{CD} 44^{\text {hi }} \mathrm{T}$ cells from WT and Itk revealed that they had similar proliferative responses to IL-2, in agreement with their expression of $\mathrm{CD} 122$, while the $\mathrm{CD} 8^{+} \mathrm{CD} 44^{\mathrm{lo}}$ population did not proliferate to any significant extent (Fig. 3c). This population of cells also rapidly secretes IFN $\gamma$ in response to exposure to LPS in vivo, as revealed by injection of mice with LPS, followed by analysis of intracellular cytokine in $\mathrm{CD}^{+} \mathrm{CD} 44^{\mathrm{hi}} \mathrm{T}$ cells from WT and Itk null mice (data not shown). Since these cells were able to rapidly secrete IFN $\gamma$, we evaluated freshly isolated unstimulated CD8 ${ }^{+} \mathrm{CD} 44^{\text {hi }} \mathrm{T}$ cells and found that these cells carry high levels of preformed message for IFN $\gamma$, as well as high levels of the transcription factor T-Bet (compared to the $\mathrm{CD} 8^{+} \mathrm{CD} 44^{\text {lo }} \mathrm{T}$ cell population) (Fig. 3d). Thus these memory like $\mathrm{CD} 8^{+} \mathrm{T}$ cells with innate function are poised to rapidly secrete IFN $\gamma$.

\section{Itk $^{-/-}$mice exhibit enhanced clearance of Listeria dependent on CD8 ${ }^{+} \mathrm{T}$ cells}

To determine if this population of memory like T cells is involved in the response against $L$. monocytogenes, we infected WT and Itk null mice with low numbers of $L$. monocytogenes $\left(2 \times 10^{3} \mathrm{CFU}\right)$, and analyzed the spleens for bacterial numbers after three days. We recovered approximately 2 fold lower bacteria from Itk null mice than from WT mice, suggesting that Itk null mice were better able to mount an innate immune response against $L$. monocytogenes (Fig. 4a). This is most likely due to the fact that Itk null spleens contained significantly percentage as well as higher numbers of $\mathrm{CD} 8{ }^{+} \mathrm{CD} 44^{\text {hi }} \mathrm{T}$ cells compared to WT mice (see Fig. 1c). When analyzed at 7 days post infection, we could not detect any bacteria in either WT or Itk null mice indicating that eventual clearance is similar in these mice (data not shown). Macrophages have been shown to be largely responsible for bacterial clearance, and we found that stimulation of splenic cells with heat killed or live L. monocytogenes resulted in significantly enhanced TNF- $\alpha$ production by Itk ${ }^{-1-}$ splenocytes (Fig. 4b). Examination of the cells secreting TNF- $\alpha$ revealed that $\mathrm{F} 4 / 80^{+}$macrophages are the only population in splenocytes that secrete TNF- $\alpha$ in response to L. monocytogenes stimulation (data not shown), and that a significantly higher percentage of the $\mathrm{Itk}^{-/-}$macrophages secreted TNF- $\alpha$ upon stimulation (Fig. 4b). By contrast, peritoneal macrophages from the same mice secreted similar levels of TNF- $\alpha$ upon stimulation with heat killed L. monocytogenes (Fig. 4b). Note that $\mathrm{Itk}^{-/-}$and WT mice have similar numbers of macrophages in the spleen and peritoneum. These 
data suggest that splenic macrophages from Itk null mice are more responsive to $L$. monocytogenes stimulation, and that this response may contribute to the advantage that these mice have upon infection.

\section{Itk $^{-/-}$memory $\mathbf{T}$ cells reduce bacterial burden in IFNy null mice}

We reasoned that an increased numbers of $\mathrm{CD} 8^{+} \mathrm{CD} 44^{\text {hi }}$ memory like $\mathrm{T}$ cells with innate function in Itk null mice may be able to secrete elevated levels of IFN $\gamma$, resulting in increased macrophage activation in the spleen, but not in the peritoneum, where there are significantly less T cells. We therefore determined if the $\mathrm{CD} 8{ }^{+} \mathrm{CD} 44^{\text {hi }}$ population of T cells in Itk null mice could secrete IFN $\gamma$ during infection with $L$. monocytogenes. We found that $\mathrm{CD} 8{ }^{+} \mathrm{CD} 44^{\mathrm{hi}} \mathrm{T}$ cells actively secrete IFN $\gamma$ in vivo 24 hours after infection with $L$. monocytogenes (Fig. 4c).

Mice lacking IFN $\gamma$ cannot reduce bacterial burden when infected with $L$. monocytogenes due to their inability to produce IFN $\gamma$ critical for this event [17]. Indeed, Itk null mice had elevated levels of IFN $\gamma$ in the serum during infection (Fig. $4 \mathrm{~d}$ ). $\mathrm{CD} 8^{+} \mathrm{T}$ cells are critical producers of IFN $\gamma$, and we found that antibody-mediated depletion of $\mathrm{CD} 8^{+} \mathrm{T}$ cells resulted in significantly reduced ability to clear this infection in both WT and Itk null mice, indicating that CD8 ${ }^{+} \mathrm{T}$ cells play a critical role in the early innate response to the bacteria (Fig. 5a). The majority of $\mathrm{CD} 8^{+} \mathrm{T}$ cells in the ITK null mice are of the CD44hi phenotype, and we had found that ITK null mice were better at clearing the infection with $L$. monocytogenes. We therefore wanted to determine if these T cells could secrete IFN $\gamma$ and reduce bacterial burden in IFN $\gamma$ null mice, and determine if the ITK null $\mathrm{CD} 8^{+} \mathrm{T}$ cells are more effective in the anti-listeria response. We did this by determining if transfer of cells from the WT and ITK null mice could rescue antibacterial responses in the mice lacking IFN $\gamma$. Sorted total $\mathrm{CD} 8^{+} \mathrm{T}$ cells from WT and $\mathrm{Itk}^{-/-}$mice were transferred into IFN $\gamma^{-1-}$ mice, which were subsequently infected with $L$. monocytogenes. Analysis of bacterial burden in the spleen of these mice indicated that while transfer of WT CD8 $8^{+} \mathrm{T}$ cells could reduce their bacterial burden, the difference was not statistically significant ( $\mathrm{p}=0.092$ vs. control IFN $\gamma$ null mice) (Fig. $5 \mathrm{~b}$ ). By contrast, transfer of total $\mathrm{CD} 8^{+} \mathrm{T}$ cells from ITK null mice was able to significantly reduce the bacterial burden on the IFN $\gamma$ null mice (Fig. 5b). We next determine if the $\mathrm{CD} 8^{+} \mathrm{CD} 44^{\text {hi }} \mathrm{T}$ cells in WT and ITK null mice were equivalent in their ability to secrete IFN $\gamma$ and reduce bacterial burden in the IFN $\gamma$ null mice. We therefore transferred sorted $\mathrm{CD} 8^{+} \mathrm{CD} 44^{\text {hi }} \mathrm{T}$ cells from WT and Itk null mice into mice lacking IFN $\gamma$, then infected them with L. monocytogenes. Analysis of bacterial burden in the spleen of these mice showed that both WT and Itk CD $8^{+} \mathrm{CD} 44^{\text {hi }} \mathrm{T}$ cells could reduce their bacterial burden, indicating that the $\mathrm{CD} 8{ }^{+} \mathrm{CD} 44^{\mathrm{hi}} \mathrm{T}$ cells seen in Itk null mice represent the population of cells previously described ([17,21], Fig. 5b). Altogether, these data show that the $\mathrm{CD} 8{ }^{+} \mathrm{CD} 44^{\text {hi }} \mathrm{T}$ cells that develop in mice lacking signals from Itk possess innate like immune function in response to IL-12/IL-18, LPS or bacterial exposure in vitro and in vivo.

\section{Discussion}

A population of $\mathrm{T}$ cells having a memory like $\mathrm{CD} 8^{+} \mathrm{CD} 44^{\mathrm{hi}}$ phenotype has been shown to develop in the absence of classical class I molecules, and these cells possess innate immune function in their ability to rapidly secrete IFN $\gamma$ in response to signals from IL-12 and IL-18, and to infection with $L$. monocytogenes [19]. More importantly, these cells can reduce bacterial burden in L. monocytogenes infected IFN $\gamma$ null mice in an antigen non-specific manner early in the innate response against this bacteria [17]. Our work here demonstrates that in the absence of Tec kinase signals the relative percentage of a population of $\mathrm{CD} 8{ }^{+} \mathrm{CD} 44^{\mathrm{hi}} \mathrm{CD} 122^{+} \mathrm{T}$ cells increases. However, these cells behave in the same manner as WT CD8 ${ }^{+} \mathrm{CD} 44{ }^{\text {hi }} \mathrm{CD} 122^{+} \mathrm{T}$ cells in rapidly secreting IFN $\gamma$ in response to stimuli from IL-12/IL-18 and infection with $L$. monocytogenes, suggesting that Tec kinase signals are not required for this function. We also 
find that these cells carry preformed message for IFN $\gamma$ as well as T-bet, suggesting a mechanism for their ability to rapidly secrete this cytokine.

The origin of $\mathrm{T}$ cells with a $\mathrm{CD} 8{ }^{+} \mathrm{CD} 44^{\mathrm{hi}}$ phenotype is controversial. Activation of naïve $\mathrm{T}$ cells in vitro generates a population of cells that have this phenotype, and the presence of the CD44 marker on T cells has been used to identify previously activated T cells [31-33]. In addition different $\mathrm{T}$ cell memory populations have been identified based on expression of CD44 and CD62L, including effector memory and central memory T cells [34]. Thus the expression of the CD44 marker on $\mathrm{CD} 8^{+} \mathrm{T}$ cells seem to represent those cells that have been previously activated and may have effector or memory function.

Similar populations of $\mathrm{CD} 8^{+} \mathrm{CD} 44^{\text {hi }} \mathrm{T}$ cells have been reported in mice lacking classical class I molecules and $\mathrm{T}$ cells with this phenotype appear to be class $1 \mathrm{~b}$ restricted $[16,22,35]$. These $T$ cells are reported to be thymic-independent in origin and carry CD122, which may distinguish them from memory $\mathrm{T}$ cells, although this distinction is not always clear since older studies on memory $\mathrm{T}$ cells did not examine this marker [36]. While it has been suggested that these cells appear due to stimulation by normal flora, they are also present in germ-free mice [37]. H2M3 restricted $\mathrm{T}$ cells can have a similar $\mathrm{CD} 8^{+} \mathrm{CD} 44^{\text {hi }}$ phenotype and can rapidly respond to L. monocytogenes infection compared to antigen specific $\mathrm{T}$ cell responses, although this $\mathrm{H} 2-$ M3 specific expansion of these cells peaks at around 7 days, while the secretion of IFN $\gamma$ by cells with a similar phenotype in response to IL-12/IL-18 induced by LPS activated macrophages is much quicker $[19,38-41]$.

However, transfer of naïve $\mathrm{T}$ cells into lymphopenic mice can also generate $\mathrm{T}$ cells bearing the CD44 marker, and these cells can take on an effector function. Similarly, individuals who have had a bone marrow transplant, and elderly individuals and mice have elevated percentages of $T$ cells with a similar phenotype [42-45]. In addition, viral and other infections can lead to expanded populations of $\mathrm{T}$ cell bearing this phenotype [20]. The appearance of these cells may represent homeostatic expansion of $\mathrm{T}$ cells to fill niches left empty by irradiation (during bone marrow transplant), reduced $\mathrm{T}$ cell output (in elderly individuals), viral exhaustion of antigen specific $\mathrm{T}$ cells, expansion of class $1 \mathrm{~b}$ restricted $\mathrm{T}$ cells, or may represent "true memory" cells. It is possible that the immune system uses such a system of expanding $\mathrm{CD} 8^{+} \mathrm{T}$ cells with this phenotype (i.e. during homeostatic expansion, cells take on an "innate-effector" phenotype) to ensure that time of lymphopenia does not result in an immunocompromised position.

It is possible that there are several distinct population of $\mathrm{CD} 8^{+} \mathrm{CD} 44^{\mathrm{hi}} \mathrm{T}$ cells that contain pools of true memory $\mathrm{T}$ cells as well as cells that have undergone rapid homeostatic expansion such as those seen in class $1 \mathrm{~b}$ restricted $\mathrm{T}$ cells, in lymphopenic mice, in cases of infections or class $1 \mathrm{~b}$ restricted $\mathrm{T}$ cells. The increased relative percentage of these cells in mice lacking Tec kinase signals may be the result of entry of $\mathrm{CD} 8^{+} \mathrm{T}$ cells into a lymphopenic compartment early in the development of these mice, leading to homeostatic expansion and the acquisition of this $\mathrm{CD} 44^{\mathrm{hi}} \mathrm{CD} 122^{+}$phenotype. These cells would then have "innate-like" effector function with preformed IFN $\gamma$ message and the ability to rapidly secrete this cytokine upon stimulation with IL-12/IL-18 or infection with L. monocytogenes. Alternatively, these cells may be selected on class $1 \mathrm{~b}$ molecules, which result in homeostatic expansion of these $\mathrm{T}$ cells and the acquisition of the $\mathrm{CD} 8{ }^{+} \mathrm{CD} 44^{\text {hi }} \mathrm{CD} 122^{+}$phenotype.

Recently, Dubois et al, Broussard et al and Atherly et al reported finding similar populations of $\mathrm{CD} 8{ }^{+} \mathrm{CD} 44^{\mathrm{hi}} \mathrm{CD} 122^{+} \mathrm{T}$ cells in mice lacking Itk [24] or Itk/Rlk [22,23], however, these investigators did not determine if these cells were functional in vivo, or related to the population of $\mathrm{CD} 8{ }^{+} \mathrm{CD} 44^{+} \mathrm{T}$ cells previously reported to rapidly respond to bacterial infection, LPS or $\mathrm{IL}-12 / \mathrm{IL}-18$ in vitro and in vivo [16-19,21]. It is unlikely that these $\mathrm{CD} 8{ }^{+} \mathrm{CD} 44^{\mathrm{hi}} \mathrm{CD} 122^{+} \mathrm{T}$ cells are memory $\mathrm{T}$ cells as the latter are usually $\mathrm{CD} 122^{-/ \mathrm{lo}}[36]$. Our data presented here suggest 
that the memory-like $\mathrm{CD} 8^{+} \mathrm{CD} 44^{\text {hi }} \mathrm{T}$ cell populations are equivalent in WT and Itk null mice, and represent an innate like population of $\mathrm{T}$ cells.

Our data also indicates that the increased serum IFN $\gamma$ observed in L. monocytogenes infected $\mathrm{Itk}^{-1-}$ mice is likely to be due to the increased numbers of these $\mathrm{CD} 8^{+} \mathrm{CD} 44^{\mathrm{hi}} \mathrm{T}$ cells in these mice, since transfer of these cells into IFN $\gamma$ null mice can reduce bacterial burden in these mice, indicating that T cell-derived IFN $\gamma$ is sufficient for this event. This increase in IFN $\gamma$ could lead to more effective macrophage activation and provide the ITK null mice with an advantage in the macrophage response to listeria. Interestingly, while the absence of Tec kinase signals results in an enhanced relative percentage of these cells, the "innate-type" function of these cell does not seem to be affected by the absence of Itk in that similar percentage of these cells produce IFN $\gamma$ upon stimulation in vitro or in vivo compared to their WT counterparts. In addition, when equal numbers of WT and $\mathrm{Itk}^{-/-} \mathrm{CD} 8^{+} \mathrm{CD} 44^{\mathrm{hi}} \mathrm{T}$ cells are transferred into IFN $\gamma$ null mice, they behave similarly in being able to reduce bacterial burden. Given that $\mathrm{T}$ cell receptor mediated stimulation is reduced in the absence of Itk, these data suggest that the "innate" response of these cells is Itk independent.

Taken together our data indicate that in the absence of signals from Tec kinases such as Itk, there is an increased population of $\mathrm{CD} 8^{+} \mathrm{T}$ cells with a memory like phenotype and innate function that can rapidly secrete cytokine in vivo in response to bacterial infection as well as LPS.

\section{Materials and Methods}

\section{Mice and bacterial infections}

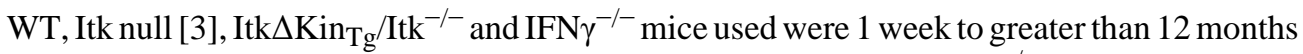
of age and were kept in specific pathogen free conditions. Itk $\Delta \mathrm{Kin}_{\mathrm{Tg}} / \mathrm{Itk}^{-1-}$ were generated by cloning a mutant Itk with the kinase domain replaced with EGFP [29], into a transgenic expression cassette driven by the Lck proximal promoter and CD2 enhancer (kind gift of Dr. Anuradha Ray, University of Pittsburgh). These mice were backcrossed to the C57BL/6 background $>10$ generations. All other mice were on the same background. Experiments were approved by the IACUC at Pennsylvania State University. Mice (age matched 6-8 weeks old) were infected with erythromycin-resistant $L$. monocytogenes $\left(2 \times 10^{3} \mathrm{CFU}\right.$, kind gift of Dr. Hao Shen, University of Pennsylvania) and sacrificed after 72 hours (similar results were observed after 24 and 48 hours). Bacterial CFU were determined by plating splenic extracts on BHI agar containing $5 \mu \mathrm{g} / \mathrm{ml}$ erythromycin. To analyze $\mathrm{T}$ cell secretion of cytokine ex vivo following infection, mice were infected with $L$. monocytogenes $\left(2 \times 10^{3} \mathrm{CFU}\right)$ for $24 \mathrm{hrs}$, and splenocytes isolated and incubated in vitro with Brefeldin A $(10 \mu \mathrm{g} / \mathrm{ml})$ for a further 6 hours, followed by analysis of intracellular IFN $\gamma$ as described below. Analysis of secretion of IFN $\gamma$ in vivo was analyzed as previously described [46]. $\mathrm{CD} 8^{+} \mathrm{T}$ cells were depleted by injection of $1 \mathrm{mg}$. antiCD8 mAb (YTS168.4, kind gift of Dr. Eric Harvill, Penn State University) and 24 hours later, infected with bacteria as described above, followed by analysis 3 days later. In experiments where $\mathrm{CD} 8^{+} \mathrm{CD} 44^{\mathrm{hi}} \mathrm{T}$ cells were transferred into IFN $\gamma$ null mice, $3 \times 10^{6}$ sorted CD $8^{+} \mathrm{CD} 44^{\mathrm{hi}}$ $\mathrm{T}$ cells were transferred into these mice, then the mice were infected with $2 \times 10^{3} \mathrm{CFU} L$. monocytogenes. Mice were analyzed at 3 days post infection.

\section{Real-Time PCR analysis}

$\mathrm{CD} 8^{+} \mathrm{CD} 44^{\mathrm{lo}}$ or $\mathrm{CD} 8^{+} \mathrm{CD} 44^{\mathrm{hi}} \mathrm{T}$ cells were sorted from the spleens of WT and Itk null mice using a Cytopeia inFlux Cell Sorter (Cytopeia Inc., Seattle, WA), and quantitative RT-PCR performed using primer/probe sets for IFN- $\gamma$ and T-bet, with GAPDH as a housekeeping gene as described [10]. Data was analyzed using the Comparative CT (threshold cycle) method and 
normalized to GAPDH. The relative gene expression levels were then determined by comparing to the expression found in the $\mathrm{WT} \mathrm{CD} 8{ }^{+} \mathrm{CD} 44^{10}$ populations, which were set at 1 .

\section{In vitro analysis of cytokine secretion and proliferation}

Splenocytes were stimulated with $50 \mathrm{ng} / \mathrm{ml} \mathrm{PMA} / 0.5 \mu \mathrm{M}$ Ionomycin for 6 hours, or IL-12 (5 $\mathrm{ng} / \mathrm{ml}, \mathrm{R} \& D$ Systems, Minneapolis, MN) and IL-18 (10 ng/ml, MBL, Watertown, MA) overnight, in the presence of Brefeldin $(10 \mu \mathrm{g} / \mathrm{ml})$ and analyzed for intracellular IFN $\gamma$ and cell surface CD8 and CD44 by flow cytometry using specific antibodies. Splenocytes or peritoneal macrophages were incubated with heat killed $L$. monocytogenes for 6 hours, and analyzed for TNF- $\alpha$ using a specific ELISA (R\&D Systems) or intracellular TNF $\alpha$ in $\mathrm{F} 4 / 80^{+}$cells by flow cytometry. To analyze responses to IL-2, sorted $\mathrm{CD} 8{ }^{+} \mathrm{CD} 44^{\mathrm{hi}}$ from WT and $\mathrm{Itk}^{-/}$mice were stimulated at $1 \times 10^{5} /$ well in triplicate with recombinant murine IL-2 $(250 \mathrm{U} / \mathrm{ml})$ for 3 days and proliferation measured by $\mathrm{H}^{3}$-thymidine incorporation.

\section{Data analysis}

Statistical evaluation was conducted by using the Student $t$ test with a probability value of $P$ $\leq .05$ considered statistically significant.

\section{Abbreviations Used}

Itk, Interleukin-2 Inducible T cell kinase; Rlk, Resting Lymphocyte Kinase; T-bet, T-box expressed in T cells.

\section{Acknowledgments}

We thank Meg Potter for animal care, Susan Magargee, Nicole Bem and Elaine Kunze at the Center for Quantitative Cell Analysis as well as Dr. Deb Grove in the Nucleic Acids Facility at the Huck Institute for Life Sciences at Penn State for flow cytometric and Q-RTPCR analysis. We also thank members of August lab for comments and feedback, the Center for Molecular Immunology \& Infectious Disease (supported by in part under a grant from the Pennsylvania Department of Health), the laboratory of Pamela Correll for assistance with peritoneal macrophages, and Dr. Cindy McKinney at the Penn State transgenic facility for the generation of transgenic mice. This work was supported by NIH grants AI051626 and AI065566, and the AHA to AA. JH is a Graduate fellow of the Huck Institutes for Life Sciences.

\section{References cited}

1. August A, Gibson S, Kawakami Y, Kawakami T, Mills G, Dupont B. CD28 is associated with and induces the immediate tyrosine phosphorylation and activation of the Tec family kinase ITK/EMT in the human Jurkat leukemic T-cell line. Proc Natl Acad Sci USA 1994;91:9347-9351. [PubMed: 7524075]

2. Schaeffer E, Debnath J, Yap G, McVicar D, Liao X, Littman D, Sher A, Varmus H, Lenardo M, Schwartzberg P. Requirement for Tec kinases Rlk and Itk in T cell receptor signaling and immunity. Science 1999;284:638-641. [PubMed: 10213685]

3. Liao X, Littman D. Altered T cell receptor signaling and disrupted T cell development in mice lacking Itk. Immunity 1995;3:757-769. [PubMed: 8777721]

4. Liu K, Bunnell S, Gurniak C, Berg L. T cell receptor-initiated calcium release is uncoupled from capacitative calcium entry in Itk-deficient T cells. J Exp Med 1998;187:1721-1727. [PubMed: 9584150]

5. Ragin M, Hu J, Henderson A, August A. A role for the Tec family kinase ITK in regulating SEB induced Interleukin-2 production in vivo via c-jun phosphorylation. BMC Immunol 2005;6:19-30. [PubMed: 16042784]

6. Fowell D, Shinkai K, Liao X, Beebe A, Coffman R, Littman D, Locksley R. Impaired NFATc Translocation and Failure of Th2 Development in Itk Deficient CD4 T Cells. Immunity 1999;11:399_ 409. [PubMed: 10549622] 
7. Schaeffer E, Yap G, Lewis C, Czar M, McVicar D, Cheever A, Sher A, Schwartzberg P. Mutation of Tec family kinases alters T helper cell differentiation. Nat Immunol 2001;2:1183-1188. [PubMed: 11702066]

8. Au-Yeung B, Katzman S, Fowell D. Cutting edge: Itk-dependent signals required for CD4+ T cells to exert, but not gain, Th2 effector function. J Immunol 2006;176:3895-3899. [PubMed: 16547221]

9. Mueller C, August A. Attenuation of Immunological Symptoms of Allergic Asthma in Mice Lacking the Tyrosine Kinase ITK. J Immunol 2003;170:5056-5063. [PubMed: 12734350]

10. Ferrara T, Mueller C, Sahu N, Ben-Jebria A, August A. Reduced airway hyperresponsiveness and tracheal responses during allergic asthma in mice lacking tyrosine kinase inducible T-cell kinase. $\mathrm{J}$ Allergy Clin Immunol 2006;117:780-786. [PubMed: 16630934]

11. Bachmann M, Littman D, Liao X. Antiviral immune responses in Itk-deficient mice. J. Virol 1997;71:7253-7257. [PubMed: 9311799]

12. Atherly L, Brehm M, Welsh R, Berg L. Tec kinases Itk and Rlk are required for CD8+ T cell responses to virus infection independent of their role in CD4+ T cell help. J Immunol 2006;176:1571-1581. [PubMed: 16424186]

13. Swain S, Agrewala J, Brown D, Jelley-Gibbs D, Golech S, Huston G, Jones S, Kamperschroer C, Lee W, McKinstry K, Roman E, Strutt T, Weng N. CD4+ T-cell memory: generation and multifaceted roles for CD4+ T cells in protective immunity to influenza. Immunol Rev 2006;211:8-22. [PubMed: 16824113]

14. Gourley T, Wherry E, Masopust D, Ahmed R. Generation and maintenance of immunological memory. Semin Immunol 2004;16:323-333. [PubMed: 15528077]

15. Dhanji S, Chow M, Teh H. Self-antigen maintains the innate antibacterial function of self-specific CD8 T cells in vivo. J Immunol 2006;177:138-146. [PubMed: 16785508]

16. Su J, Berg R, Murray S, Forman J. Thymus-dependent memory phenotype CD8 T cells in naive B6. $\mathrm{H}-2 \mathrm{~Kb}-/-\mathrm{Db}-/-$ animals mediate an antigen-specific response against Listeria monocytogenes. J Immunol 2005;175:6450-6457. [PubMed: 16272298]

17. Berg R, Crossley E, Murray S, Forman J. Memory CD8+ T cells provide innate immune protection against Listeria monocytogenes in the absence of cognate antigen. J Exp Med 2003;198:1583-1593. [PubMed: 14623912]

18. Kambayashi T, Assarsson E, Lukacher A, Ljunggren H, Jensen P. Memory CD8+ T cells provide an early source of IFN-gamma. J Immunol 2003;170:2399-2408. [PubMed: 12594263]

19. Berg R, Cordes C, Forman J. Contribution of CD8+ T cells to innate immunity: IFN-gamma secretion induced by IL-12 and IL-18. Eur J Immunol 2002;32:2807-2816. [PubMed: 12355433]

20. Braaten D, McClellan J, Messaoudi I, Tibbetts S, McClellan K, Nikolich-Zugich J, Virgin H IV. Effective Control of Chronic gamma-Herpesvirus Infection by Unconventional MHC Class IaIndependent CD8 T Cells. PLoS Pathogens 2006;2:e37. [PubMed: 16733540]DOI: 10.1371/ journal.ppat.0020037

21. Berg R, Forman J. The role of CD8 T cells in innate immunity and in antigen non-specific protection. Curr Opin Immunol 2006;18:338-343. [PubMed: 16616476]

22. Broussard C, Fleischecker C, Horai R, Chetana M, Venegas A, Sharp L, Hedrick S, Fowlkes B, Schwartzberg P. Altered development of CD8+ T cell lineages in mice deficient for the tec kinases Itk and Rlk. Immunity 2006;25:93-104. [PubMed: 16860760]

23. Atherly L, Lucas J, Felices M, Yin C, Reiner S, Berg L. The Tec family tyrosine kinases Itk and Rlk regulate the development of conventional CD8+ T cells. Immunity 2006;25:79-91. [PubMed: 16860759]

24. Dubois S, Waldmann T, Muller J. ITK and IL-15 support two distinct subsets of CD8+ T cells. Proc Natl Acad Sci U S A 2006;103:12075-12080. [PubMed: 16880398]

25. Miller AT, Berg LJ. Defective Fas Ligand Expression and Activation-Induced Cell Death in the Absence of IL-2-Inducible T Cell Kinase. J Immunol 2002;168:2163-2172. [PubMed: 11859102]

26. Walzer T, Arpin C, Beloeil L, Marvel J. Differential in vivo persistence of two subsets of memory phenotype CD8 T cells defined by CD44 and CD122 expression levels. J Immunol 2002;168:27042711. [PubMed: 11884436] 
27. Dombroski D, Houghtling R, Labno C, Precht P, Takesono A, Caplen N, Billadeau D, Wange R, Burkhardt J, Schwartzberg P. Kinase-independent functions for Itk in TCR-induced regulation of Vav and the actin cytoskeleton. J Immunol 2005;174:1385-1392. [PubMed: 15661896]

28. Grasis J, Browne C, Tsoukas C. Inducible T cell tyrosine kinase regulates actin-dependent cytoskeletal events induced by the T cell antigen receptor. J Immunol 2003;170:3971-3976. [PubMed: 12682224]

29. Hao S, Qi Q, Hu J, August A. A kinase independent function for Tec kinase ITK in regulating antigen receptor induced serum response factor activation. FEBS Lett 2006;580:2691-2697. [PubMed: 16631752]

30. Nomura T, Kawamura I, Tsuchiya K, Kohda C, Baba H, Ito Y, Kimoto T, Watanabe I, Mitsuyama M. Essential role of interleukin-12 (IL-12) and IL-18 for gamma interferon production induced by listeriolysin O in mouse spleen cells. Infect Immun 2002;70:1049-1055. [PubMed: 11854182]

31. Murali-Krishna K, Ahmed R. Cutting edge: naive T cells masquerading as memory cells. J Immunol 2000;165:1733-1737. [PubMed: 10925249]

32. Cho B, Rao V, Ge Q, Eisen H, Chen J. Homeostasis-stimulated proliferation drives naive T cells to differentiate directly into memory T cells. J Exp Med 2000;192:549-556. [PubMed: 10952724]

33. Lau L, Jamieson B, Somasundaram T, Ahmed R. Cytotoxic T-cell memory without antigen. Nature 1994;369:648-652. [PubMed: 7516038]

34. Sallusto F, Geginat J, Lanzavecchia A. Central memory and effector memory T cell subsets: function, generation, and maintenance. Annu Rev Immunol 2004;22:745-763. [PubMed: 15032595]

35. Urdahl K, Sun J, MJ B. Positive selection of MHC class Ib-restricted CD8+ T cells on hematopoietic cells. Nat. Immunol 2002;3:772-779. [PubMed: 12089507]

36. Yamada H, Matsuzaki G, Chen Q, Iwamoto Y, Nomoto K. Reevaluation of the origin of CD44(high) "memory phenotype" CD8 T cells: comparison between memory CD8 T cells and thymusindependent CD8 T cells. Eur J Immunol 2001;31:1917-1926. [PubMed: 11433389]

37. Dobber R, Hertogh-Huijbregts A, Rozing J, Bottomly K, Nagelkerken L. The involvement of the intestinal microflora in the expansion of CD4+ T cells with a naive phenotype in the periphery. Dev. Immunol 1992;2:141-150. [PubMed: 1386544]

38. Seaman M, Wang C, Forman J. MHC class Ib-restricted CTL provide protection against primary and secondary Listeria monocytogenes infection. J Immunol 2000;165:5192-5201. [PubMed: 11046052]

39. Kerksiek K, Busch D, Pilip I, Allen S, Pamer E. H2-M3-restricted T cells in bacterial infection: rapid primary but diminished memory responses. J Exp Med 1999;190:195-204. [PubMed: 10432283]

40. Busch D, Pilip I, Vijh S, Pamer E. Coordinate regulation of complex T cell populations responding to bacterial infection. Immunity 1998;8:353-362. [PubMed: 9529152]

41. Kambayashi T, Assarsson E, Lukacher A, Ljunggren H, Jensen P. Memory CD8+ T cells provide an early source of IFN-gamma. J Immunol 2003;170:2399-2408. [PubMed: 12594263]

42. Ernst D, Weigle W, Noonan D, McQuitty D, MV H. The age-associated increase in IFN-gamma synthesis by mouse CD8+ T cells correlates with shifts in the frequencies of cell subsets defined by membrane CD44, CD45RB, 3G11, and MEL-14 expression. J. Immunol 1993;151:575-587. [PubMed: 7687616]

43. Jackola D, Ruger J, Miller R. Age-associated changes in human T cell phenotype and function. Aging 1994;6:25-34. [PubMed: 8043623]

44. Gorla R, Airo P, Ferremi-Leali P, Rossi G, Prati E, Brugnoni D, Cattaneo R. Predominance of 'memory' phenotype within CD4+ and CD8+ lymphocyte subsets after allogeneic BMT. Bone Marrow Transplant 1993;11:346-347. [PubMed: 8097938]

45. Stachel D, Futterer A, Haas R, Schmid I. Enhanced lymphocyte proliferation responses in pediatric patients early after myelosuppressive chemotherapy. Pediatr Blood Cancer 2004;43:644-650. [PubMed: 15390295]

46. Liu F, Whitton J. Cutting Edge: Re-evaluating the In Vivo Cytokine Responses of CD8+ T Cells during Primary and Secondary Viral Infections. J Immunol 2005;174:5936-5940. [PubMed: 15879085] 
a

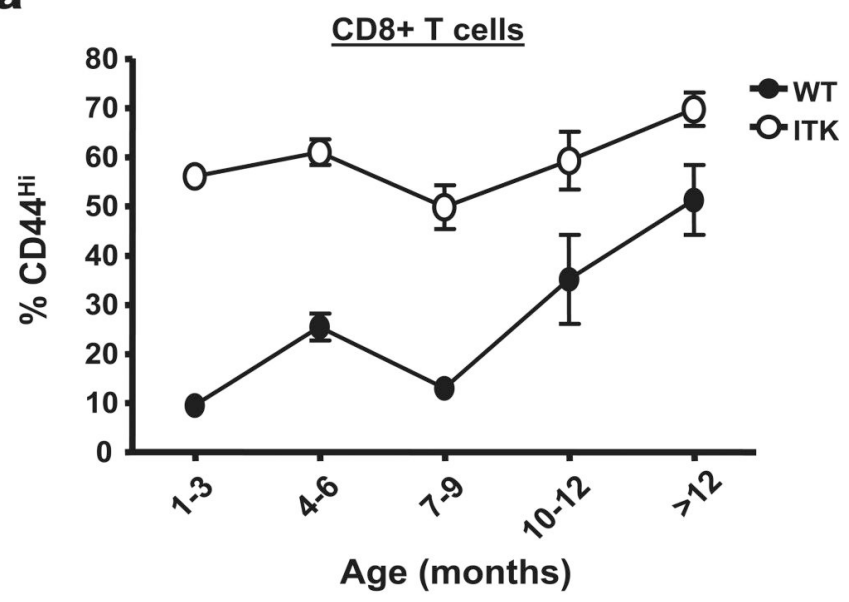

b

\section{CD8+ T cells}

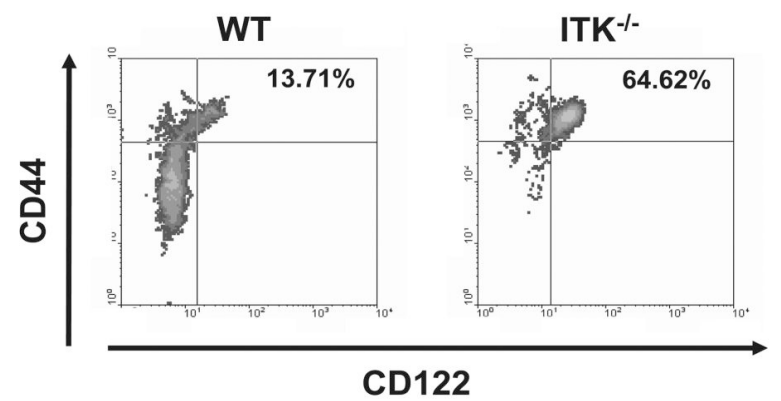

c

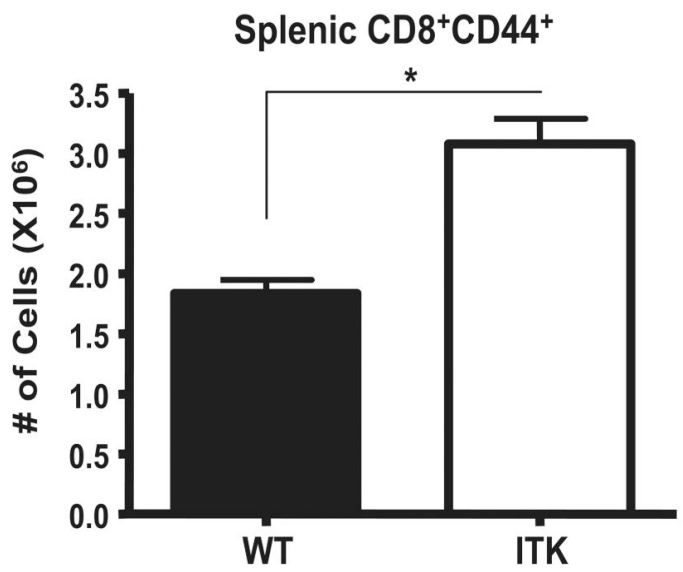

Figure 1.

Increased percentage of $\mathrm{CD}^{+} \mathrm{CD} 44^{\mathrm{hi}}$ memory phenotype $\mathrm{T}$ cells in mice lacking Itk. (a) Spleens from WT and $\mathrm{Itk}^{-/-}$mice were analyzed for the percentage of CD8 ${ }^{+} \mathrm{CD} 44^{\text {hi }}$ cells over the indicated time frame. (b) Analysis of CD44 and CD122 expression on CD8 ${ }^{+} \mathrm{T}$ cells in WT and Itk null mice. (c) Number of $\mathrm{CD}^{+} \mathrm{CD} 44^{\text {hi }} \mathrm{T}$ cells in the spleens of WT and $\mathrm{Itk}^{-/-}$mice. $(* \mathrm{p}=0.0007, \mathrm{n}=5)$. 
a

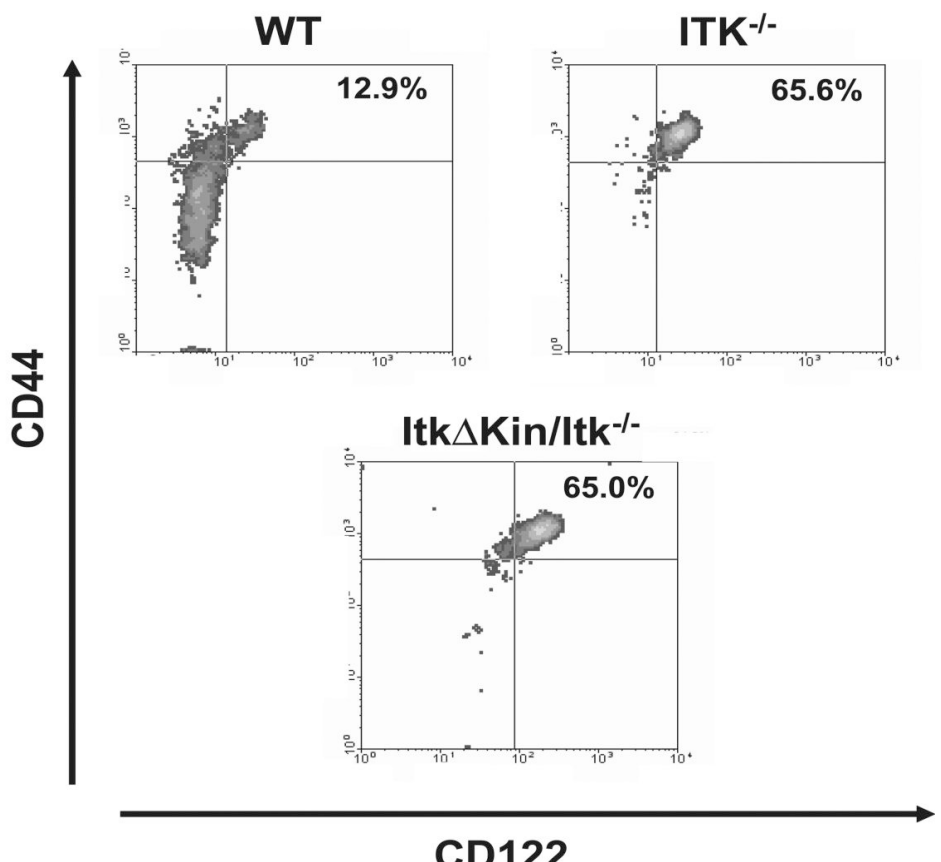

b

\section{$\underline{\mathrm{CD}^{+}{ }^{+} \mathrm{CD} 44^{\mathrm{hi}}}$}

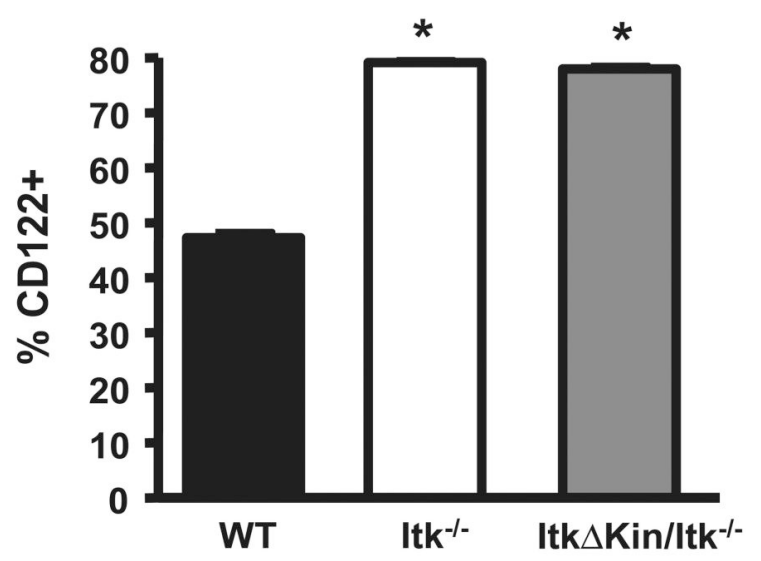

Figure 2.

Active Tec kinase signaling regulates the presence of $\mathrm{CD} 8{ }^{+} \mathrm{CD} 44^{\text {hi }}$ memory like $\mathrm{T}$ cells. (a) Spleens from WT, $\mathrm{Itk}^{-/-}$and Itk $\Delta \mathrm{Kin}_{\mathrm{Tg}} / \mathrm{Itk}^{-/-}$mice were analyzed for the percentage of $\mathrm{CD}^{+} \mathrm{CD} 44^{\text {hi }} \mathrm{CD} 122^{+}$cells. (b) Percentage of $\mathrm{CD} 8{ }^{+} \mathrm{CD} 44^{\text {hi }} \mathrm{T}$ cells that carry CD122 in the indicated mice $(* \mathrm{p}<0.05$; NS. Not statistically significant vs. WT mice). 

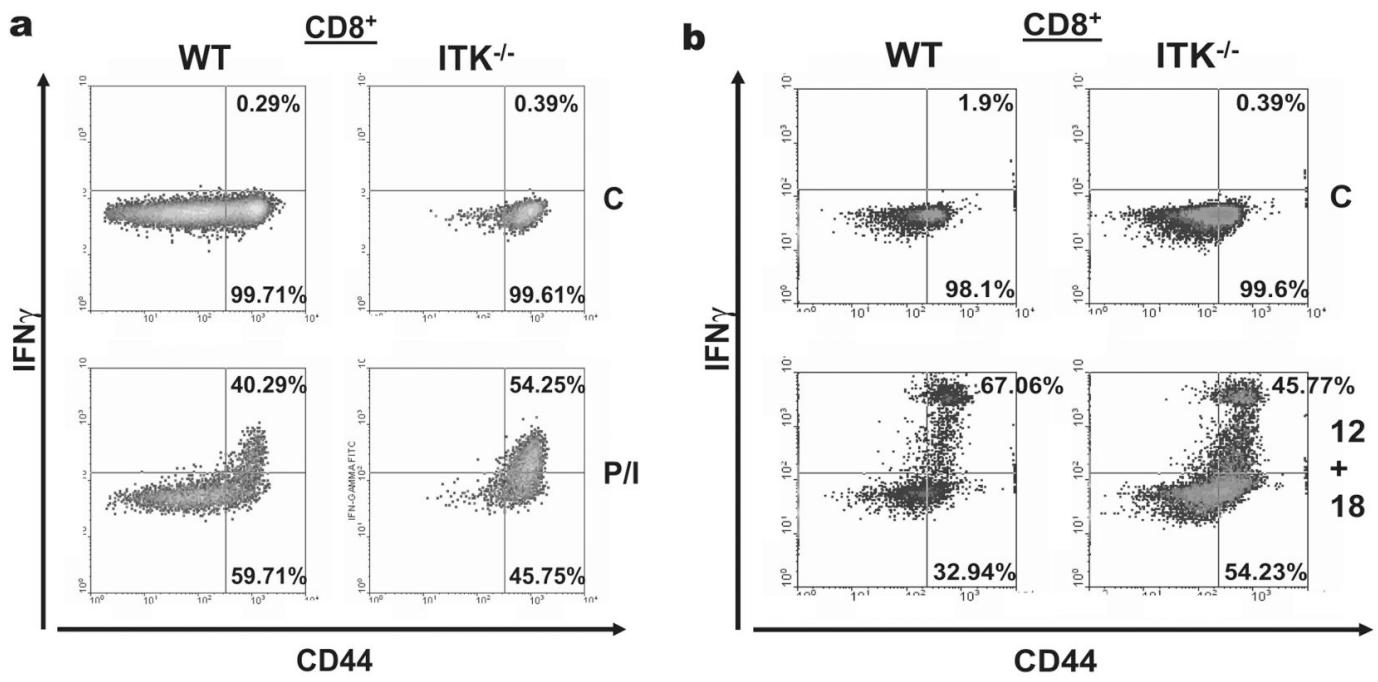

C

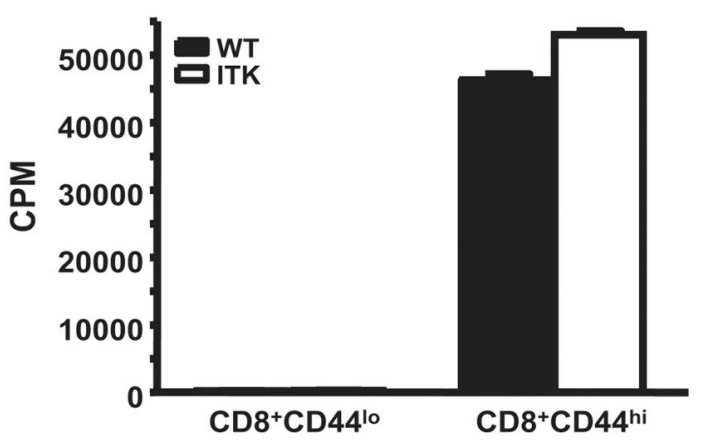

d

$\underline{\text { IFN } \gamma}$

$\underline{\text { T-bet }}$
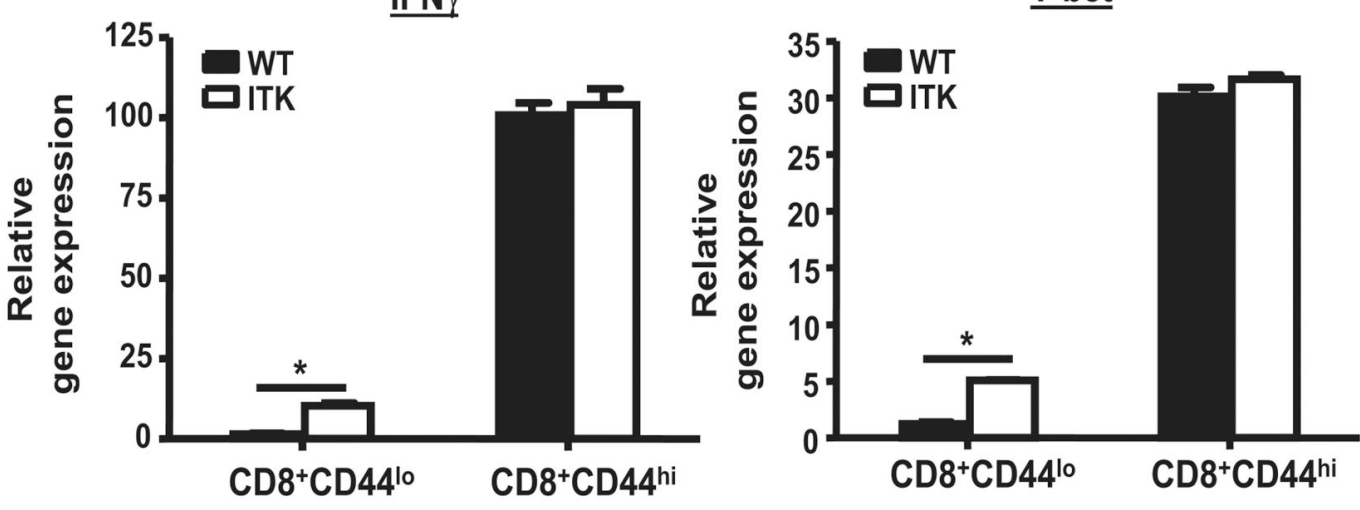

Figure 3.

$\mathrm{CD} 8^{+} \mathrm{CD} 44^{\text {hi }} \mathrm{T}$ cells rapidly secrete IFN $\gamma$ upon activation with IL-12/IL-18. (a) Splenocytes from WT and $\mathrm{Itk}^{-/-}$mice were stimulated with PMA/Ionomycin followed by analysis for intracellular IFN $\gamma$ in gated $\mathrm{CD}^{+} \mathrm{T}$ cells. (b) Similar experiments as described in (a) except that cells were stimulated with IL-12 and IL-18. Percentages shown in (a) and (b) indicate those $\mathrm{CD}^{+} \mathrm{CD} 44^{\text {hi }}$ that respond to stimulation (upper right) and those that did not respond (lower right). (c) Purified $\mathrm{CD}^{+} \mathrm{CD} 44^{\text {hi }}$ from WT and $\mathrm{Itk}^{-/-}$mice were stimulated with IL-2 for 3 days and proliferation measured by $\mathrm{H}^{3}$-thymidine incorporation. (d) $\mathrm{CD} 8^{+} \mathrm{CD} 44^{\mathrm{hi}}$ and $\mathrm{CD} 8{ }^{+} \mathrm{CD} 44^{\text {lo }} \mathrm{T}$ cells from WT and $\mathrm{Itk}^{-/-}$mice were sorted by flow cytometry and message for IFN $\gamma$ (left) and T-bet (right) analyzed by QRT-PCR. Data are corrected for GAPDH 
expression and expressed as fold over the $\mathrm{WT} \mathrm{CD} 8{ }^{+} \mathrm{CD} 44^{\text {lo }}$ populations, which was set at 1 . ${ }^{*} \mathrm{p}<0.05$, NS, not statistically significant vs. WT mice. 
a

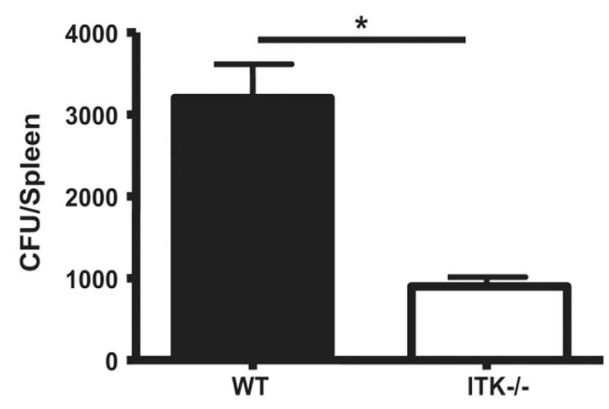

C

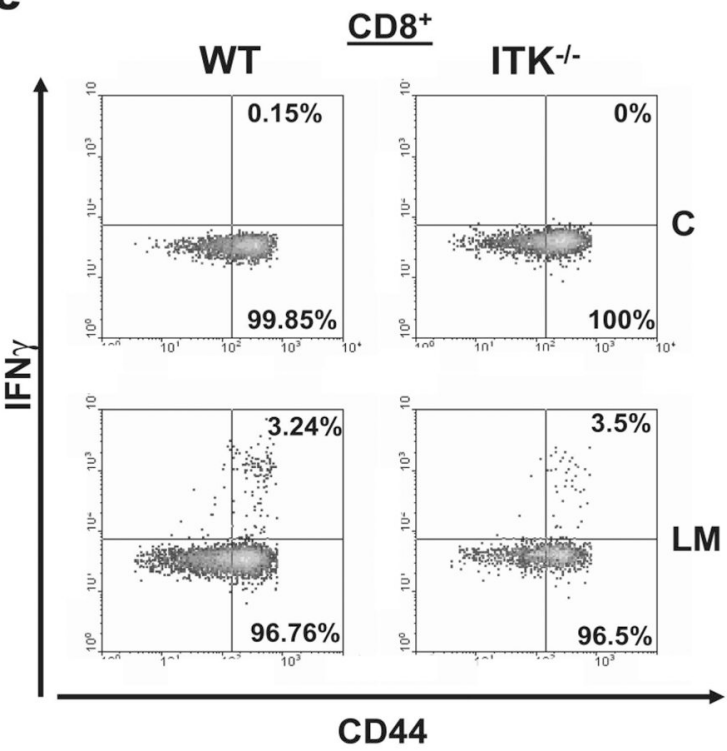

b
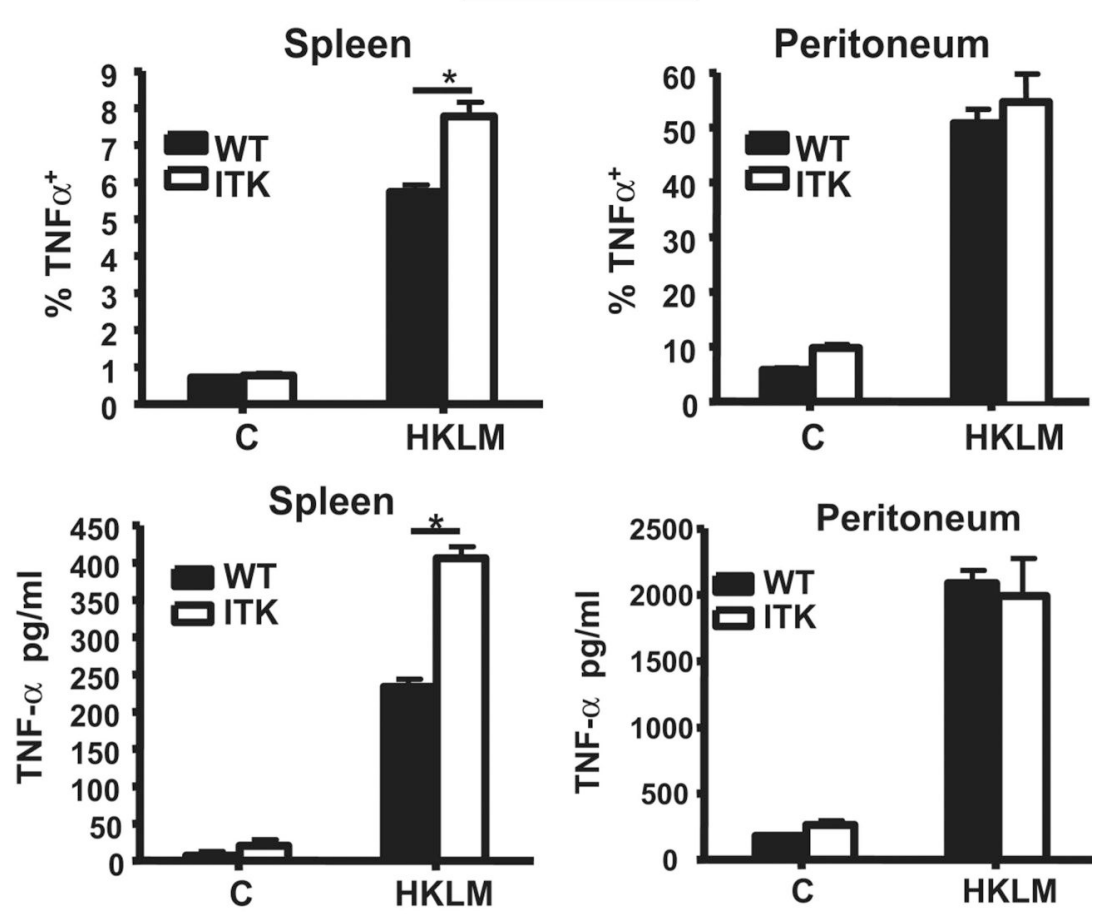

d

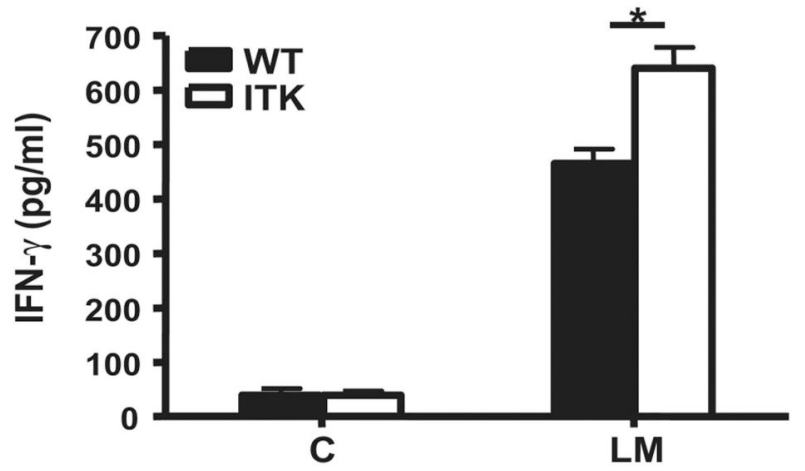

Figure 4.

$\mathrm{CD} 8{ }^{+} \mathrm{CD} 44^{\text {hi }} \mathrm{T}$ cells respond to infection with $L$. monocytogenes in vivo. (a) WT and $\mathrm{Itk}^{-1-}$ mice were infected with $2 \times 10^{3} \mathrm{CFU} L$. monocytogenes for 3 days and the number of bacteria in the spleen determined ( ${ }^{*} p<0.05$ vs. WT mice). (b) Splenocytes (left panels) or peritoneal macrophages (right panels) from WT and $\mathrm{Itk}^{-1-}$ mice were stimulated in vitro with HKLM and cells analyzed for the percentage of $\mathrm{TNF} \alpha^{+} \mathrm{F} 4 / 80^{+}$macrophages by flow cytometry (top panels) or supernatants analyzed for TNF $\alpha$ by ELISA (bottom panels). (c) WT and Itk ${ }^{-l-}$ mice were infected with $2 \times 10^{3} \mathrm{CFU}$ L. monocytogenes, and 24 hrs later, splenocytes harvested and $\mathrm{CD} 8^{+} \mathrm{CD} 44^{\text {hi }} \mathrm{T}$ cells analyzed for intracellular IFN $\gamma$. Percentages shown indicate those $\mathrm{CD} 8{ }^{+} \mathrm{CD} 44^{\text {hi }}$ that respond to stimulation (upper right) and those that did not respond (lower 
right). ( ${ }^{*} \mathrm{p}<0.05$ vs. WT mice). (d) WT and $\mathrm{Itk}^{-1-}$ mice were infected $2 \times 10^{4} \mathrm{CFU} L$. monocytogenes for 2 days and serum IFN $\gamma$ determined by ELISA ( ${ }^{*} \mathrm{p}<0.05$ vs. WT mice). 

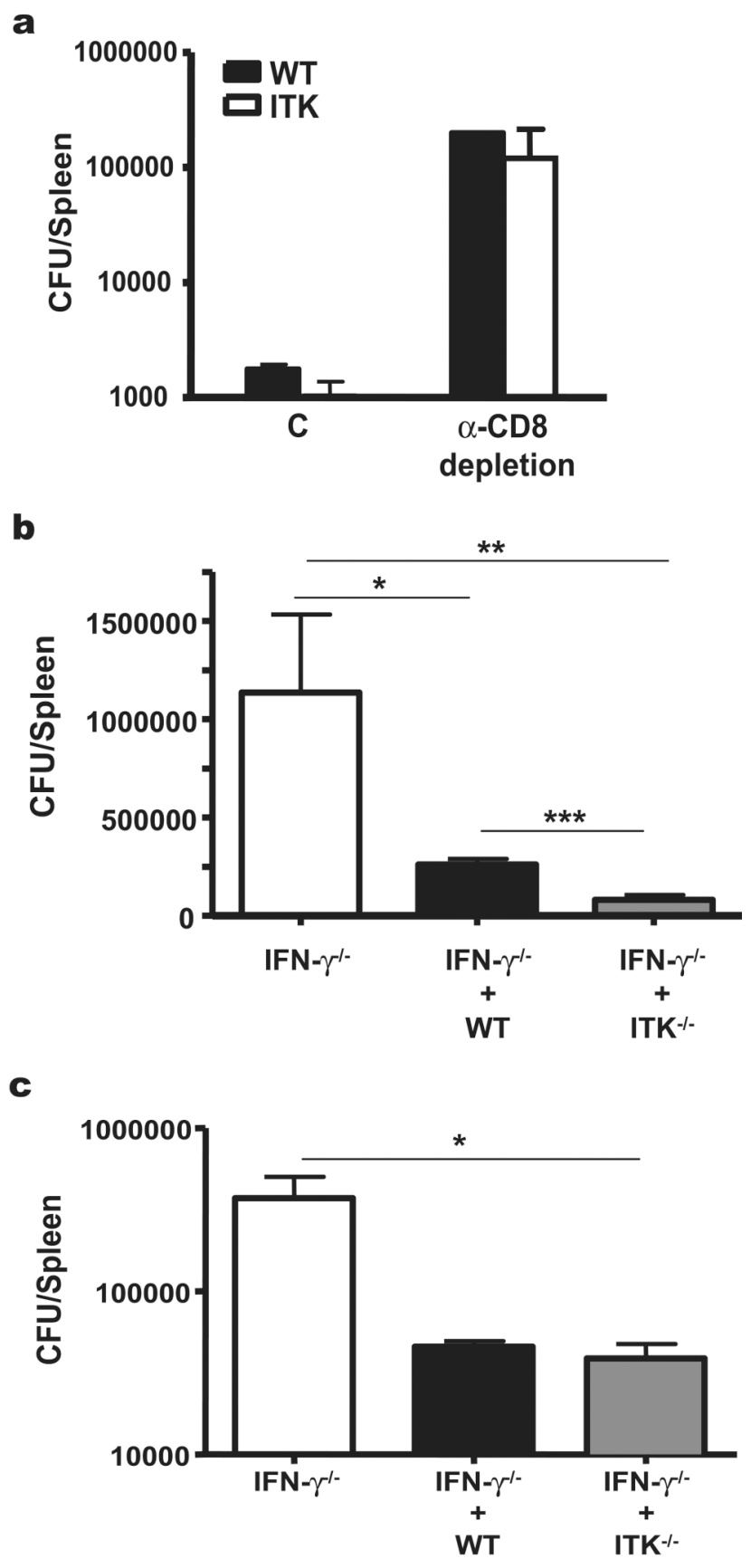

Figure 5.

$\mathrm{CD} 8{ }^{+} \mathrm{CD} 44^{\text {hi }} \mathrm{T}$ cells reduce bacterial burden in IFN $\gamma$ null mice infected with $L$. monocytogenes. (a) $\mathrm{CD}^{+} \mathrm{T}$ cells were depleted from WT and $\mathrm{Itk}^{-1-}$ mice, and the mice infected with L. monocytogenes 24 hours later. Mice were then analyzed as described in figure 4. (b) Sorted total $\mathrm{CD}^{+} \mathrm{T}$ cells from WT and $\mathrm{Itk}^{-/-}$mice were transferred into IFN $\gamma^{-1-}$ mice, which were subsequently infected with $2 \times 10^{3} \mathrm{CFU}$ L. monocytogenes for 3 days and the number of bacteria in the spleen determined as in figure $4\left(* \mathrm{p}=0.092\right.$ for recipients of $\mathrm{WT}^{-/-} \mathrm{T}$ cells vs. IFN $\gamma^{-1-}$ mice; $* * \mathrm{p}<0.05$ for recipients of $\mathrm{ITK}^{-1-} \mathrm{T}$ cells vs. IFN $\gamma^{-1-}$ mice; $* * \mathrm{p}<0.01$ for recipients of WT T cells vs. ITK ${ }^{-1-} \mathrm{T}$ cells). (c) Sorted $\mathrm{CD} 8^{+} \mathrm{CD} 44^{\text {hi }} \mathrm{T}$ cells from WT and $\mathrm{Itk}^{-/-}$mice were transferred into IFN $\gamma^{-/-}$mice, which were subsequently infected with 
$2 \times 10^{3} \mathrm{CFU}$ L. monocytogenes for 3 days and the number of bacteria in the spleen determined as in figure $4\left(* \mathrm{p}<0.05\right.$ vs. IFN $\gamma^{-1-}$ mice $)$. 